\title{
Economic Regionalization and Black Sea in a Comparative Perspective
}

\author{
$\operatorname{Arzu} \mathrm{AL}^{*}$ \\ Hakan MEHMETCÍK**
}

\begin{abstract}
Since the end of the Cold War, the study of regions has become a major preoccupation of political scientists. And yet, regionalism still means many different things to many different peoples in too many different contexts. Nonetheless, economic interdependences through trade and other intraregional activities is one of the main pillar of regionalization in any given example. The driving impulse of this paper is that there is a hypothetical relation with emerging regional economic relations and regionalism. That is, regionalism and emerging regional economic activities self-enforcing phenomena at least on theoretical front. In this sense, it is sensible to look at the some of the trade and economic statistics to determine the state of regionalization in the Black Sea. Therefore, this paper first tries to demarcate "Black Sea Region" and possible sub regions than will comparatively analyses the economic regionalization process by comparing some other regions and sub regions. The main finding of the paper suggests that fundamentally due to the fact that every member of Black Sea regions has been engaging with other exclusive regionalization movements, regionalization in the wider Black Sea is weak and underdeveloped.
\end{abstract}

Keywords: Regionalism, Black Sea as a Region, Comparative Regionalism, Trade and Economy in Black Sea, BSEC.

\section{Karşılaştırmalı Bir Çerçeveden Ekonomik Bölgeselleşme ve Karadeniz}

\section{Öz}

Soğuk Savaşın bitişinden bu yana bölgelerin çalışılması siyaset bilimi çalışmaları içerisinde öncelikli bir alan haline gelmeye başladı. Fakat hala bölgeselcilik birçok kişi için bir sürü farklı bağlamda oldukça farklı anlamlara geliyor. Yine de ekonomik karşılıklı bağımlılık ve bölge içi artan ticaret herhangi bir

Asst. Prof. Dr. Arzu Al, Marmara University, Faculty of Political Science, Department of International Relations, arzu.al@marmara.edu.tr

** Research Asst. Hakan Mehmetcik, Marmara University, Faculty of Political Science, Department of International Relations, hakan.mehmetcik@marmara.edu.tr 
bölgeselcilik örneği için olmazsa olmaz koşullardan bir tanesi. Bu çalışmanın temel hareket noktası da bölgeselcilik ve ekonomik aktivitenin bölgeselleşmesi arasında teoride kurulan bu bağdır. Bu bağlamda, Karadeniz'de bölgeseliciliğe ya da bölgeselleşmeye bakmanın bir yöntemi ekonomik aktivitenin bölgeselleşmesinin incelenmesi olacaktır. Bu çalışmanın amacı da ticaret ve ekonomik aktivite verileri üzerinden Karadeniz bölgesini, muhtemel alt bölgeleri diğer bölgeselcilik örnekleri ile karşılaştırmaktır. Fakat bu çalışmanın en temel bulgusu Karadeniz bölgesindeki ülkelerin birbiriyle rekabet halinde olan farklı bölgeselcilik projeleri içerisinde yer almalarından dolayı, bu bölgede bölgeselcilik zayıf ve gelişmemiş durumdadır.

Anahtar kelimeler: Bölgeselcilik, Karadeniz Bölgesi, Karşılaştırmalı Bölgeselcilik, Karadeniz'de Ticaret ve Ekonomi, KEİ.

\section{Introduction}

One of the major puzzles that political scientists have tried to address over the last two decades is the emergence of regions and regional integration movements as regions have become widely referred both as an unit of analysis and as a level of analysis within the study of International Relations (IR). Not only have regions become substantially more important topics of IR compare to what it was a decade ago, but they have also acquired substantial autonomy from the system level interactions of the global power (Lake and Morgan 1997: 49) and they become a direct influencer of the systemic level developments from trade regimes to alliance formations. Yet, regionalism means many different things to many different peoples in too many different contexts (Börzel and Risse 2016: 1). Indeed, what constitutes a region and what regionalism is an ongoing discussion among scholars (Fawcett 2004; Lawrence 1996; Panagariya 1999). At most common characterization, regionalism starts with an economic imperative (regionalization of economic activities) in which groups of countries comprise a trading block through free trade agreements (FTA) and regional trade agreements (RTAs) or, in advance level, a custom union (CUs) and then move further by establishing an institutional regionalization dynamic. States incorporate first in economic areas and this first level integration catalyze further integration in other areas. This voyage from regionalization of economy to institutional regionalism is what theory of functionalism, which widely associated with David Mitrany, suggests (David 1933; Mitrany 1948). Thus, economic imperative seems one of the, if not the most, important stage of regionalism. Therefore, the driving impulse of this study is that there is a hypothetical relation with emerging bilateral/multilateral trade relations within a defined geography and regionalism at the institutional level. In this sense, regionalism and formation of a regional economy are self-enforcing phenomena at least on theoretical front. Nonetheless, when we look at the Black Sea as a region, it is still an open question whether there is a trade dynamic that can possibly lead an economic regionalization process that can be characterize as a facilitator of greater regional integration in the long run. This study tries to look at the trade 
statistics and some other figures on FTAs/RTAs to determine whether there is a potential of economic regionalization/sub-regionalization in the region. To do that, the paper first surveys regionalization of economic activities in the form of FTAs/RTAs in the world. Then, it compares and contrast economic activities in the form of trade in other regions to build a ground to scrutinize the regionalization processes of the Black Sea. In the last part, the paper shifts its focus on the Black Sea by looking at the trade dynamics and competing regionalization routes. Departing from these empirical analyses the paper will show how and why these competing regionalization courses impedes the regionalization of economic activities in the Black Sea.

\section{Multilateralism vs Regionalism in Trade Politics}

Globalization trends make the world of nations more connected than ever. Our clothes are mostly manufactured in developing countries; our computers are designed in developed world while assembled by some other countries from components of coming from other parts of the world (Oatley 2012: 21). As a direct result of the new labor of production patterns, the rapid growth in trade has brought us into a new level of globalization. Global trade has grown more over 10 times since the end of the WW II. As Oatley points out "Never before in history has international trade grown so rapidly for such a long period" (Oatley 2012: 22). Without a working political structure that supports world trade, such uninterrupted rapid growth would not have been possible. Here, one of the most important multilateral structure is WTO and its predecessor GATT (General Agreement on Tariffs and Trade). WTO has been around almost 20 years now and played an important role in internalization of trade by providing governments a rule based interaction forum. Yet, the stability of trade regimes in the world, as Oatley himself accepts, is a function of the distribution of power in international relations (Oatley, 2012:29). This pure academic suggestion can be empirically proved through analyzes of regional trading blocs. WTO may be the linchpin of organization of the world trade as a multilateral forum, yet the trade is still a regional phenomenon via FTAs/RTAs implemented in specific regions. ${ }^{1}$ Indeed, regionalism through the FTAs/RTAs is an appealing alternative to organize trading relations among countries. Therefore, many observers believe that regional trade arrangements pose the single greatest challenge to the multilateral trade system designed and implemented by WTO (Oatley 2012: 36).

FTAs and Economic Unions are the separate end of the same diagram (regional integration). Between these there are Custom Unions, Common Markets. In this sense, the differences between these different regional trade arrangements are just in degree not in kind. See (Ravenhill 2014, 174) 
Figure I: Evaluation of Trade Agreements (1948-2016) ${ }^{2}$

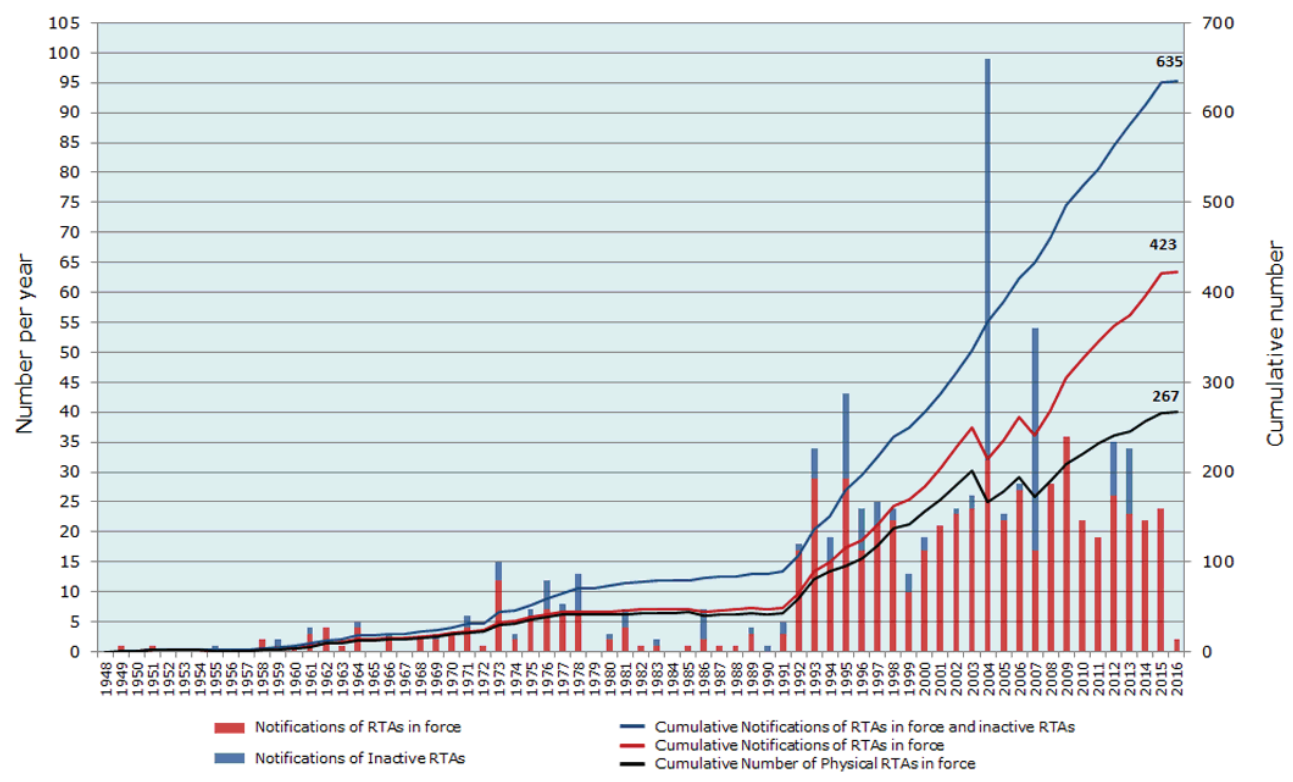

Source: WTO

FTAs/RTAs and $\mathrm{CUs}^{3}$ come to be established when countries remove tariffs and barriers to the free movement of goods and services and peoples in a specific area. In this sense, FTAs is the first step of the process that transform regionalization ${ }^{4}$ into regionalism. ${ }^{5}$ There is an explosion in the numbers of FTAs/RTAs/CUs over the last decades. RTAs are not necessarily threat to multilateralism per se as they are the most important exception that WTO permits (Ravenhill, 2014:173). Yet, when we look at the figures we see that FTA constitutes the vast majority of existing more than 400 RTAs, of which more than half are bilateral. That's why these RTAs have been seen a dangerous development to multilateralism in trade.

In this sense, the question is why nations choose to RTAs over other multilateral trade institutions. There are some political motivations. Countries can use economic cooperation as a confidence building mechanism for political ends or they pursue security guarantees among members even up to a point building as security community where interdependence is so high that war is excluded as a way of solving conflicts. Regionalism can be a bargaining tool as well as it can facilitate reforms including satisfaction of domestic constituencies and ease of negotiating and implementing agreements. There are economics motivations as well. Regionalism serve better for

\footnotetext{
2 The figure is retrieved from http://bit.ly/2iZraIz)

3 Custom Unions are generally more multilateral and deeper arrangements than regional trade agreements (RTAs).

4 Regionalization means a high degree of economic interdependence.

5 Regionalism refers to a formal intergovernmental cooperation over numbers of issues.
} 
the protection of sectors that would not survive in global competition. In this sense, regionalism is a more secure form of integration vis-a-vis multilateralism. Regionalism provides better forum for a faster and deeper integration whereas multilateralism, especially WTO or CUs, cannot enable governments such steps due to diverse membership. Regionalism can also serve better in enlarging economic of scales (enlarging markets) and increasing investment opportunities (Ravenhill, 2014: 178). Therefore, there is a rush for regionalism in the world and therefore we need to dwell more on regionalism to examine evolution of international trade systems.

When we look at the some of the chief example of regionalization process through RTAs, two things appear obvious. First of all, intra-regional trade goes hand in hand with regionalization. Second, institutionalized regionalism processes are not always far more successful than the others. For instance, we look at the raw trade statistics listed in the figure below, we see that intra-regional trade within APEC, EU, BRICS, SADC, SAARC and in many other have been growing in unpresented numbers over the last 20 years. The trade among BRICS countries has grown more 17 times, it is more than 9 times when it comes to SAARC. The growth numbers are 8 times for ECCAS, 6 times for COMESA, 8 times for OIC respectively. When it comes to more institutionalized regionalism movements, for EU in particular, intra-trade has grown well over $129 \%$, for APEC the number is over $243 \%$, for CIS over $151 \%$. These sheer numbers confirm that intra-regional trade is, indeed, growing almost every regional groupings even though there are ups and downs along the way, especially after the 2008 global financial crises.

These increasing intra-regional trade is one of the direct result of successfully implemented FTAs/ RTAs and CUs. Nevertheless, this is somehow counterproductive in terms of regionalization since these create powerful incentive for expanding of trade within a region by removing tariffs and barriers to the free movement of goods and services and peoples, yet it also hinders globalization and trades by preventing entry by other countries in the same region. From this perspective, RTAs are competitive among each other and in many instance, they de/re-regionalizes some specific regions. One of the most obvious example of de-re-regionalized region by the competing RTAs is Black Sea. 
Figure 2: Change in Regional Economic Activities in some Selected Regions
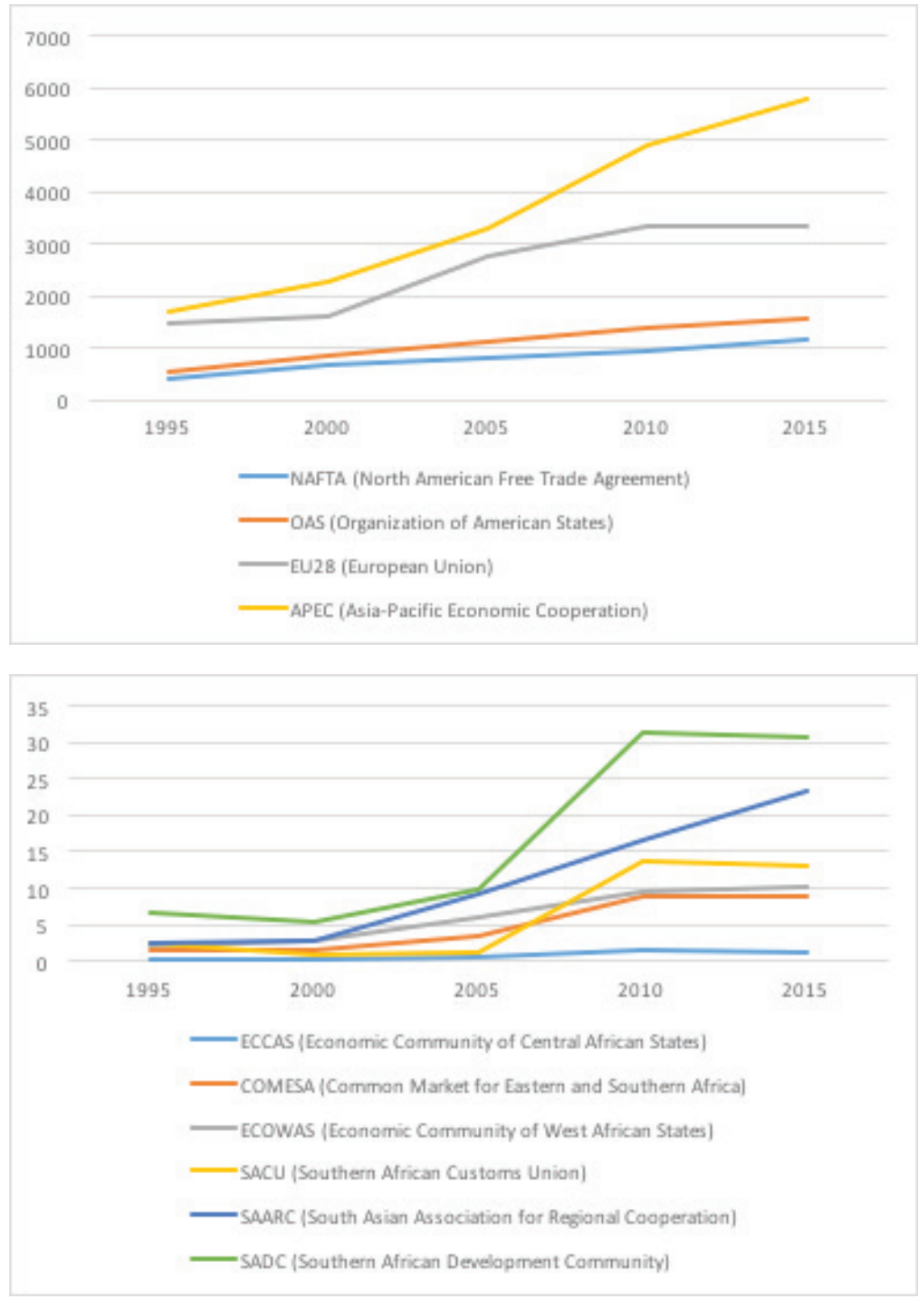


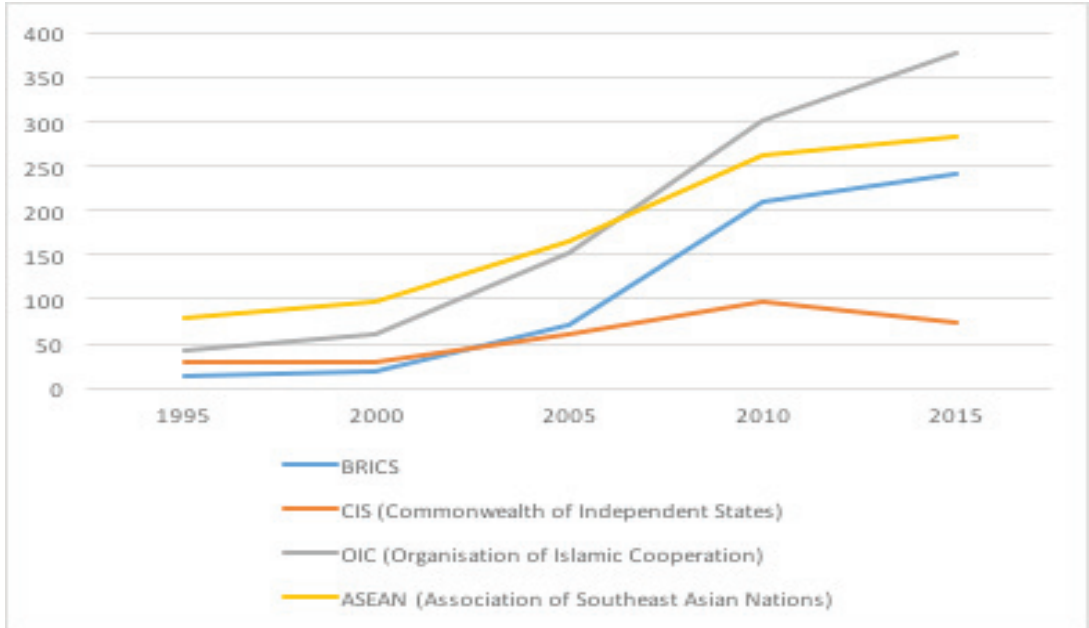

- Numbers represents the total of all import/export in given years and all are in current \$billion dollars.

- Graphics are made by the aouthors upon the data retrieved from UNCTAD.

The Data Source: http://unctad.org/en/Pages/statistics.aspx

\section{Regionalization in the Black Sea}

The Black Sea Economic Cooperation (BSEC) was established in June 1992 by the governments of eleven states and in 2004 Serbia and Montenegro have joined in. Albania, Armenia, Azerbaijan, Bulgaria, Georgia, Greece, Moldova, Romania, Russia, Turkey, Ukraine, Serbia and Montenegro are the member of the BSEC, which is the most advanced expression of the regional cooperation in the region. Indeed, the BSEC identity evolved from a diplomatic conference model into a fully-fledged regional economic organization endowed with international legal personality, institutional autonomy and standing organs (Celac and Manoli 2006). Initially, BSEC was designed to a trade facilitation tool even though it has moved beyond pure economic issues over the years. It has both an intergovernmental structure with a decision-making body Council of Ministers of Foreign Affairs (CMFA), a permanent secretariat based in Istanbul, Turkey, a business dimension with BSEC Business Council, a financial pillar with Black Sea Trade and Development Bank (BSTDB), Parliamentary Assembly of the Black Sea Economic Cooperation (PABSEC) and a research dimensions with International Center for Black Sea Studies (ICBSS). Even though BSEC is neither a trade bloc nor a security community, cooperation within BSEC covers a broad spectrum of activities such as trade and investments, energy, transport and communications, environment, tourism, Small-Medium-sized Enterprises (SMEs), combating organized crime and other non-conventional threats, dealing with emergency situations, institutional renewal and improved governance. However, giving rise closer economic ties through trade facilitation is the 
most realistic goal, which is also as it is also acknowledged by BSEC (Celac and Manoli 2006). Therefore, BSEC is an apt departure point for any study of regionalization in the Black Sea region.

However, when we evaluate the regionalization process (regionalization of economic activities) in the Black Sea among BSEC members, intra-regional trade is not growing as fast as other regional groupings experience over the last decade. For instance, BSEC to BSEC trade has increased only $41 \%$ and median growth among BSEC members for their trade with other BSEC members is only 1.88 times. The only exception to this is Turkey, which has increased its trade with other BSEC members 17 times.

Figure 3: BSEC Economic Activities with Some Selected Regions
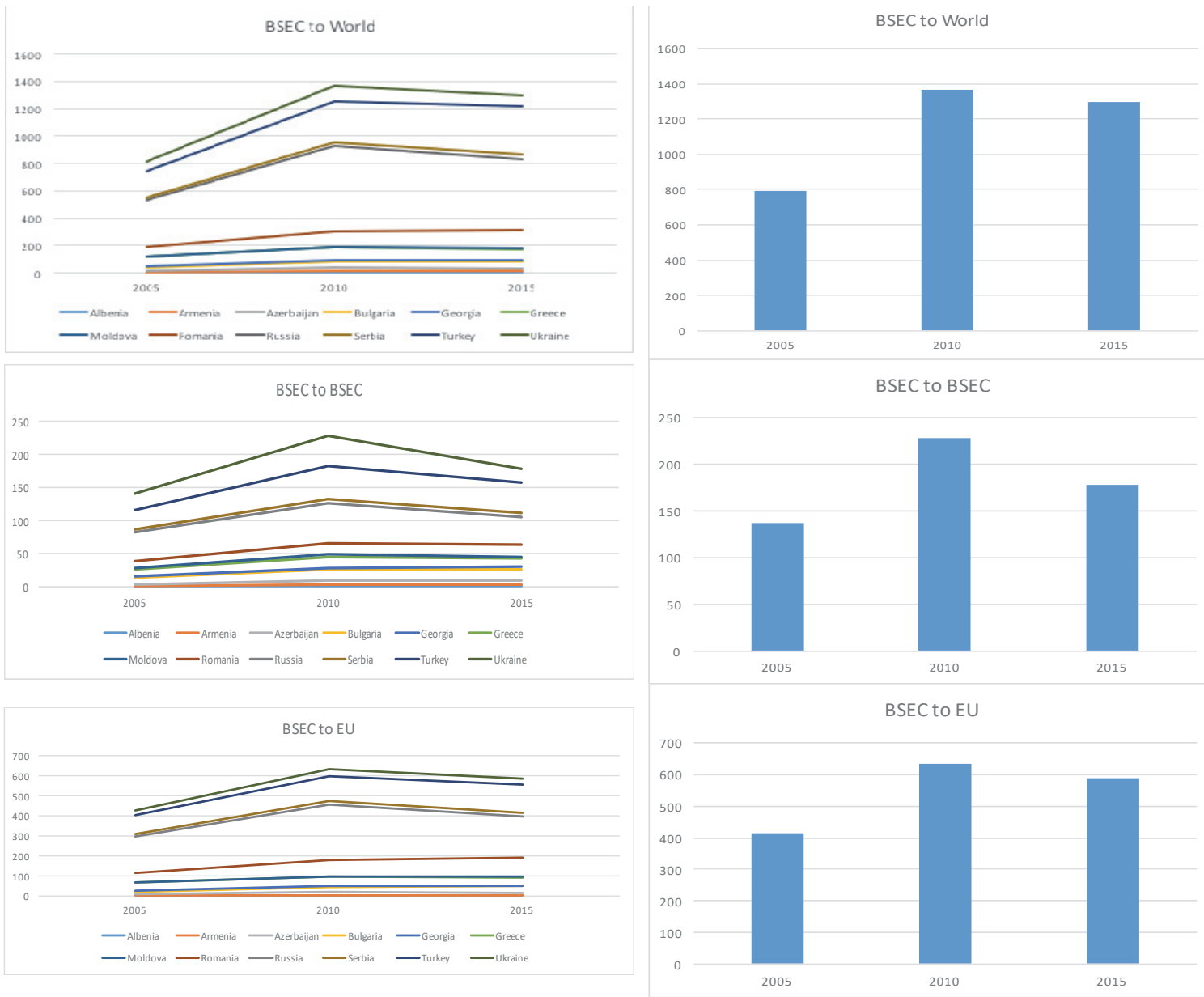

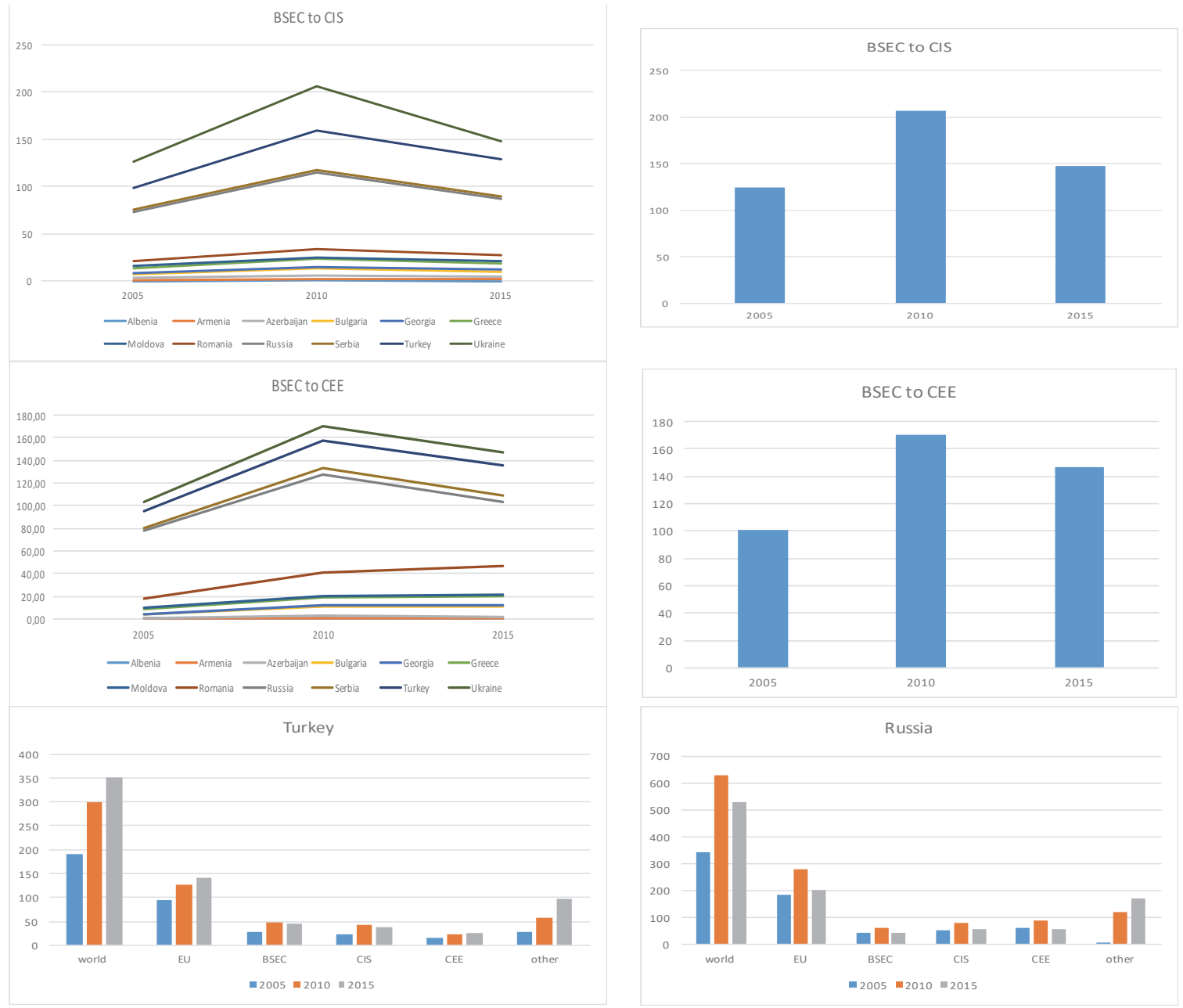

- Numbers represents total of all import/export in given years and all are current \$million dollars

- The data is collected from national statistical instutions of BSEC Member states by the aouthers. The garphics are made by the aouthors upon these data.

One of the most important reasons for this might be the global economic slow-down since 2008. Indeed, when we look at the trade statistics BSEC to other regions similar patterns can be observed. BSEC trade to EU, CIS, CEE all has been experienced sharp decline after 2010s. However, the most important reason that hinders regionalization of economic activities within BSEC is competing regionalization courses that BSEC members pursue. Indeed, BSEC countries have taken very few practical steps to liberalize trade amongst themselves and/or to harmonize their policies towards third parties (Celac and Manoli 2006). This is mainly due to the fact that BSEC countries, almost all are bound by other international obligations when it comes to trade. The table below presents 
these competing regionalization processes in BSEC area. Especially, EU led regionalism has been more attractive for many BSEC countries and most of them being a EU member states obliged to abide by EU trade policies towards third parties.(Hajizada and Marciacq 2013) In a similar way, Russia led regionalism under CIS vis-a-vis EU is another important competing trading block in the region. CEFTA is the single least important trading agreements. Besides these RTAs, there are also bounding FTAs that hinders regionalization of economic activities. In this sense, one of the motor countries in the region is Turkey whose essential target in bilateral cooperation is to establish FTAs with BSEC countries that pave the way to gradual establishment of an economic partnership based on free movement of goods and capital (Astrov and Havlik 2008). However, as it is case for RTAs, FTAs are also very much exclusive to third parties when it comes to trade. Russia is also another important country due to its closed ties with East European and Balkan countries and given its economy of scale compare to other member states. However, when we analyzed Turkish and Russian trade statistics other groups, especially EU, plays more important role.

Moreover, there are many security anxieties and historical and cultural antipathies towards each other among BSEC countries, which over all reduced the incentives to participate more integrated trade relations (Hajizada 2012). BSEC countries have remained reluctant to economic integration at a sub-regional level before reaching agreements on security issues among the regional countries such as Nagorno-Karabakh, Abkhazia, and recently Crimea conflicts. This higher political strains and given differences between BSEC members in terms of foreign policy agendas, it is not easy to assume a way forward for deeper regional integration. BSEC has also, as an institution dealing with facilitating closer economic ties among its members, numbers of drawbacks and limitations such as lack of coordination, finance, implementation and overlooking bodies (Celac and Manoli 2006). Furthermore, there is a gap between BSEC declaratory statements and realistic types of regionalism that BSEC can pursue in the current environment (Bolukbasi and Ertugral 2008).

Rivalry, conflict and cooperation are the dynamics that shaped the political economy of the Black Sea region (Manoli 2013). Given diverged interests and policies among members, institutional challenges, and the way in which regional economies organized, the regionalization of economies in the Black Sea region remains weak and underdeveloped. In this sense, regioness of the Black Sea in terms of market integration and regionalization of economies has been slow-paced. This is also true for sub-regional areas within Black Sea. For instance, none of possible candidates such as CIS, CEFTA or CEE, can wittingly claim regioness when it comes to regionalization of economies. All of these sub-groupings represents divisions but not unity even as we look at the sheer trade statistics even though there are rhetorical statements regarding with such regional communities under several different names. 
Table I: Competing Regionalization in BSEC Area

\begin{tabular}{|c|c|c|c|c|c|c|c|c|c|c|c|c|c|c|c|}
\hline 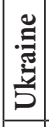 & & 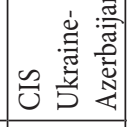 & 焉 & 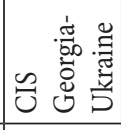 & 空 & 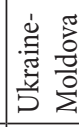 & & $\mathscr{0}$ & 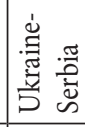 & 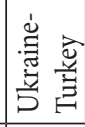 & $\not$ & & 宽 & 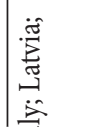 & \\
\hline 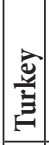 & 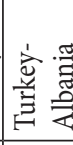 & & 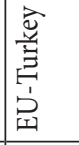 & 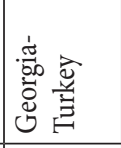 & 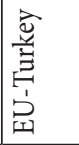 & & 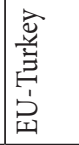 & & 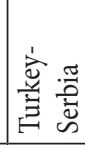 & $\not$ & 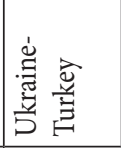 & 当 & 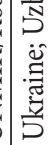 & 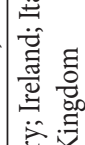 & \\
\hline 㶾 & 崫 & & 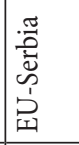 & & 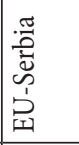 & 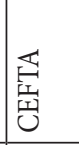 & 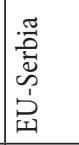 & 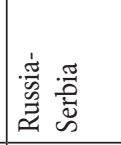 & $\not$ & 商 & 竞 & 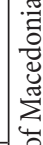 & 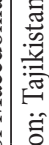 & 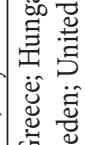 & \\
\hline 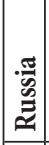 & & 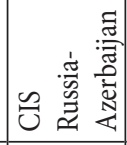 & & 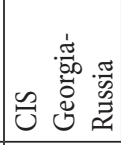 & & 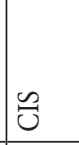 & & $\triangle$ & & & $\mathscr{\mho}$ & 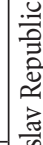 & 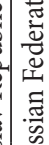 & 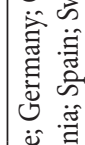 & \\
\hline 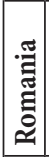 & 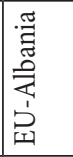 & & 로 & | & 盆 & 它 & 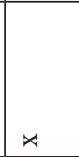 & & 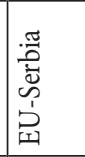 & 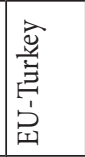 & 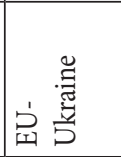 & : & 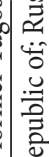 & 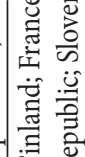 & \\
\hline 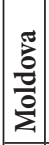 & 䧟 & $\ddot{\theta}$ & 空葶 & $\approx$ & : & $\triangle$ & 盆 & $\tilde{0}$ & 画 & & $\ddot{0}$ & 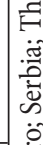 & i & 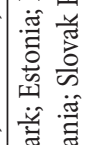 & \\
\hline 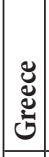 & 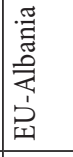 & & 虹 & 总 & $\nexists$ & 空 & 品 & & 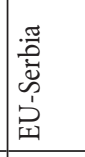 & 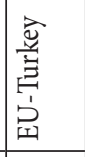 & 苟 & i. & 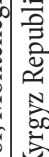 & 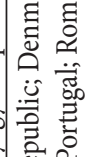 & \\
\hline 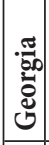 & & 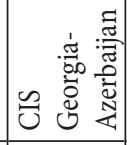 & 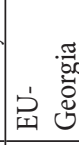 & $x$ & 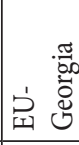 & 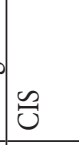 & r & 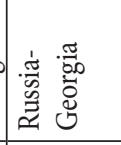 & & 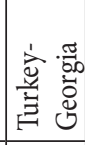 & & 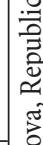 & 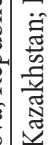 & 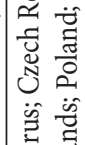 & \\
\hline 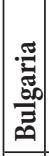 & 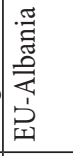 & & $x$ & . & 只 & 空 & ? & & 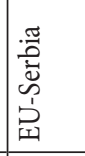 & 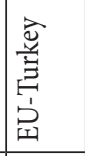 & 盆莺 & 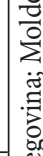 & 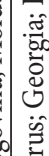 & 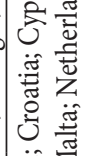 & 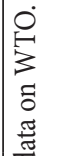 \\
\hline 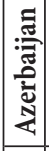 & & 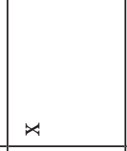 & & 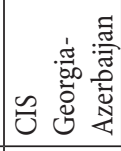 & & $\mathscr{U}$ & & 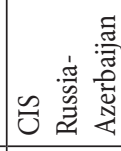 & & & ص & 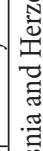 & 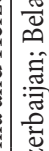 & 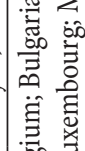 & 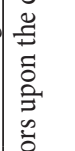 \\
\hline 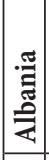 & $\star x$ & & 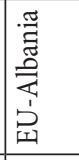 & & 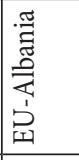 & 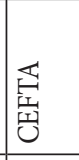 & 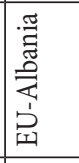 & & 画 & 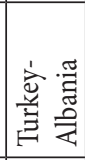 & & 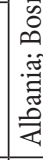 & 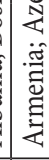 & 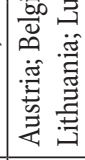 & 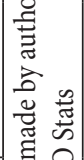 \\
\hline & 葛 & 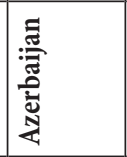 & 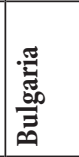 & 总 & 巡 & $\frac{\pi}{\tilde{c}}$ & 嗬 & 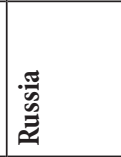 & 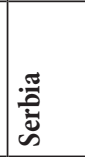 & \begin{tabular}{|l} 
\\
产 \\
音
\end{tabular} & 节 & 䆟 & $\widetilde{J}$ & 只 & 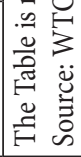 \\
\hline
\end{tabular}




\section{Conclusion}

Regionalization and regionalism are one of the most relevant eco-politic indicators of the evolving international relations of today. In this sense, reviewing, comparing and contrasting these phenomena over different time and spatial contexts makes a lot of sense. Regional integration of trade, investment, capital markets, finance and other source of people to people contacts such as tourism as regionalization of economic activities is always an apt start for greater regionalism in a specific area. In this terms, Black Sea region has numerous advantages such cultural, political and economic diversity, close geographic proximities, young and educated work force, overlapping economic-political interest, so on so forth. A regional cooperation, if not integration, is needed in the region to deal with regional economic and political problems (Manoli 2014). Moreover, for the first time its long history, with the end of the Cold War, there are apt reasons and institutions to develop a regional cooperation (Aydin 2005). In this sense, BSEC as a linchpin of regionalism desire in the region has an established track of facilitation of the economic activities among members. Nevertheless, even though a strong formal institution accompanied by rich and habitable grounds for regionalism exist on the ground, regionalization of economic activities is weak and remain underdeveloped in the Black Sea. Empirical analyses of the existing trade data and competing FTAs/RTAs show us that one of the most important factor that hinders regionalization of economic activities in Black Sea is that there are competing exclusory regionalism choices in the region. Therefore, it is not easy to assume a full-fletched regionalization process in the region for the foreseeable future. 


\section{References}

Astrov, Vasily, and Peter Havlik. (2008), "Economic Developments in the Wider Black Sea Region." 349. Vienna: Vienna Isntitute for International Economic Studies. http://www.wiiw.ac.at/economicdevelopments-in-the-wider-black-sea-region-dlp-458.pdf.

Aydin, Mustafa, (2005), "Regional Cooperation in the Black Sea and the Role of Institutions." Perceptions: Journal of International Affairs 10: 58-61.

Bolukbasi, Tolga, and Ebru Ertugral, (2008), "Regionalism and Regionalization in the Black Sea Region and Turkey.” 2012/2. Black Sea Discussion Papers. Istanbul: EDAM. http://bit.ly/2j0zxn0.

Börzel, Tanja A., and Thomas Risse, eds. (2016), The Oxford Handbook of Comparative Regionalism. Oxford, UK: Oxford University Press.

Celac, Sergiu, and Panagiota Manoli, (2006) "Towards a New Model of Comprehensive Regionalism in the Black Sea Area." Southeast European and Black Sea Studies 6 (2): 193-205. doi:10.1080/14683850600694262.

David, Mitrany, (1933), The Progress of International Government. London: Unwin Brothers LTD., Woking.

Fawcett, Louise, (2004), "Exploring Regional Domains: A Comparative History of Regionalism.” International Affairs 80 (3): 429-46. doi:10.1111/j.1468-2346.2004.00391.x.

Hajizada, Mukhtar, (2012), “Complex Regionalisation in the Wider Black Sea Area." University of Leicester. https://ra.le.ac.uk/handle/2381/27769.

Hajizada, Mukhtar, and Florent Marciacq, (2013) “New Regionalism in Europe’s Black Sea Region: The EU, BSEC and Changing Practices of Regionalism." East European Politics 29 (3): 305-27. doi:10.1080/ 21599165.2013.807800.

Lake, David A, and Patrick M. Morgan, (1997), Regional Orders: Building Security in a New World. University Park, Pa.: Pennsylvania State University Press.

Lawrence, Robert Z, (1996), Regionalism, Multilateralism, and Deeper Integration. Washington DC.: Brookings Institution Press.

Manoli, Panagiota, (2013), The Dynamics of Black Sea Subregionalism. Burlington, VT: Ashgate Publishing, Ltd.

- - . 2014. "Regional Coopertaion in the Black Sea." Commissioned Paper for the Black Sea Trade and Development Bank. http://bit.ly/2j0zR5a.

Mitrany, David, (1948), “The Functional Approach to World Organization." International Affairs (Royal Institute of International Affairs 1944-) 24 (3): 350-63. doi:10.2307/3018652.

Oatley, Thomas, (2012), International Political Economy. Pearson Longman.

Panagariya, Arvind, (1999), “The Regionalism Debate: An Overview.” World Economy 22 (4): 455-76. doi:10.1111/1467-9701.00214.

Ravenhill, John, (2014), Global Political Economy. 4 edition. Oxford ; New York, NY: Oxford University Press. 
